\title{
AGRESTIA ZEROVII (MEGASPORACEAE, LICHEN-FORMING ASCOMYCETES), A NEW SPECIES FROM SOUTHEASTERN EUROPE PROVED BY ALTERNATIVE PHYLOGENETIC ANALYSIS
}

\author{
Sergii Y. KondratyuK ${ }^{1 *}$, Alla B. Groma Kova ${ }^{2}$, Alexander Y. Khodo- \\ SovtseV ${ }^{3}$, Jung A. $\mathrm{KIM}^{4}$, Anna S. KondratiU ${ }^{4,5}$ and Jae-Seoun HUR ${ }^{4}$ \\ ${ }^{1}$ M. H. Kholodny Institute of Botany, Tereshchenkivska str. 2, 01004 Kyiv-1, Ukraine; *ksya_net@ukr.net \\ ${ }^{2}$ V. N. Karazin Kharkiv National University, Svobody Sq. 4, 61022 Kharkiv, Ukraine \\ ${ }^{3}$ Kherson State University, 40 rokiv Zhovtnia str. 27, 73000 Kherson, Ukraine \\ ${ }^{4}$ Korean Lichen Research Institute, Sunchon National University, Sunchon 540-742, Republic of Korea \\ 5'Institute of Biology' Scientific Educational Centre, Taras Shevchenko National University of Kyiv, \\ Volodymyrska str. 64/13, 01601 Kyiv, Ukraine
}

Kondratyuk, S. Y., Gromakova, A. B., Khodosovtsev, A. Y., Kim, J. A., Kondratiuk, A. S. \& Hur, J.-S. (2015): Agrestia zerovii (Megasporaceae, lichen-forming Ascomycetes), a new species from southeastern Europe proved by alternative phylogenetic analysis. - Studia bot. hung. 46(2): 69-94.

\begin{abstract}
Agrestia zerovii is described, illustrated, and compared here with closely related taxa. It is a member of the $A$. hispida complex of the steppe zone of Ukraine, southeastern Europe, and differs from $A$. hispida s. str. in having much thicker main thalline lobes, in forming thick "horizontal crust", and in the lack of black tips of secondary branchlets. The position of the newly described $A$. zerovii in the alternative combined phylogenetic tree of the Megasporaceae with all members for which reliable data on the nrITS, nrLSU, and mtSSU sequences are hitherto available is discussed. Four new robust branches and their taxonomic diversity are discussed, i.e.: the Agrestia, the Chlorangium, the Sphaerothallia s. str., and the "Circinaria" lacunosa clades being in separate position from the Circinaria s. str. clade (additionally to five genera of the Megasporaceae, i.e. Aspicilia, Circinaria, Lobothallia, Megaspora and Sagedia accepted by previous authors). The genera Agrestia, Chlorangium, and Sphaerothallia, proposed to be resurrected, and a number of aspicilioid lichens the status of which are in need of revision are discussed. Five new combinations for the species of the genus Chlorangium (C. alpicola, C. aschabadense, C. asperum, C. gyrosum, and C. sphaerothallinum) are proposed.
\end{abstract}

Key words: Agrestia, alternative combined phylogenetic analysis, Chlorangium, ITS and LSU nrDNA, 12 S SSU mtDNA, sequences

\section{INTRODUCTION}

The most comprehensive treatment of the vagrant members of the genus Aspicilia to date was published by OXNER (1971), with some additional information by ANDreeva (1987) and Sohrabi et al. (2013a) (in the latter treated as members of the genus Circinaria). Vagrant Aspicilia species are mainly known 
from arid regions in Eurasia and North Africa. They are often collectively referred to as "manna lichens" (cf. the biblical Book of Exodus 16; see Donkin $1980,1981)$. Some of the vagrant species were included in identification keys by Szatala (1957) and Poelt (1969). Nomenclatural problems involved in this group were recently discussed by SoHRABI and AHTI (2010), who also summarised the history of the group and listed the most important publications.

After Nordin et al. (2010) and OWE-Larsson et al. (2011) two "manna lichens", viz. Circinaria emiliae (Tomin) A. Nordin, S. Savič et Tibell and C. hispida (Mereschk.) A. Nordin, S. Savič et Tibell were segregated from the genus Aspicilia into the genus Circinaria for the first time. These authors recently revised the phylogeny of the Megasporaceae using a combined data set of nrLSU and $\mathrm{mtSSU}$, and accepted the division of the Megasporaceae into the following five genera, i.e.: Aspicilia A. Massal., Circinaria Link, Lobothallia (Clauzade et Cl. Roux) Hafellner, Megaspora (Clauzade et Cl. Roux) Hafellner et V. Wirth, and Sagedia Ach. Taxonomy and molecular phylogeny of the "manna lichens" have considerable developed in the last years (SoHRABI et al. 2011b, 2013a).

Status of Circinaria hispida s. str. was outlined by SoHRABI et al. (2011b, 2013a) using the same combined data set of nrLSU and mtSSU, and separate nrITS analysis. From the data of these authors Circinaria hispida s. str., a vagrant morphotype sensu MERESCH KOWSKY (1911), is characterised by subfruticose, tiny, bushy, more or less Cladonia-like thallus with narrow cylindrical branches, with black apices at the tip of the branchlets, and scattered whitish pseudocyphellae along the branches. It grows initially on soil and later becomes vagrant. Therefore, it is classified as erratic. Circinaria hispida s. str. has never been reported in fertile condition in Eurasia. So far, its fertile specimens have been reported from North America (Brodo 1976, Sohrabi et al. $2011 b$, Thomson 1961). In the nrITS analysis, C. hispida is grouped with a few Eurasian saxicolous specimens that are fertile. Therefore, the saxicolous specimens with crustose morphotype were accepted as C. hispida s. l. in contrast to the vagrant morphotypes as C. hispida s. str. (SoH RABI et al. 2013a). We follow similar terminology in this paper, too.

Ukrainian specimens previously recorded as Agrestia hispida (see OxNER 2010, KONDRATYU K et al. 2014c) were found to be different from $A$. hispida s. str. based on molecular and morphological data, i.e.: different in having distinctly swollen basal portions of the lobes (main lobes), often forming "horizontal crust", as well as in the lack of black tips of the branchlets. Furthermore, Ukrainian specimens were shown to be different when applying phylogenetic analysis based on nuclear and mitochondrial DNA sequences (KONDRATYUK et al. 2014c, and see below).

The aim of this paper is to provide legal description of a new taxon named here as Agrestia zerovii as well as to discuss its position in the phylogenetic tree 
of the Megasporaceae based on ITS1/ITS2 nrDNA, LSU nrDNA and 12S SSU mtDNA sequences. Chlorangium asperum, which was assumed to be an appropriate name for the species described below as Agrestia zerovii at the beginning of this study, was included into the phylogenetic analysis, too. Status of the genera Agrestia, Chlorangium, Sphaerothallia, and the "Circinaria" lacunosa group are briefly discussed below.

\section{MATERIAL AND METHODS}

Material was collected during several field trips to Kharkiv oblast, Ukraine in 2012 and 2013, while the locality of the new species (as Agrestia hispida) has been known since the 1940s (OXNER 2010).

Extracting DNA, sequencing and phylogenetic analysis (alignment with Clustal and manual steps, and MP, ME and ML phylogenetic methods) were done as described in our previous papers (KONDRATYUK et al. 2013, 2014a, c, 2015).

List of specimens included in the phylogenetic analysis along with their GenBank accession numbers are provided in Table 1 (a few specimens were not included in the final phylogenetic tree, Fig. 1).

The alternative combined phylogenetic analysis based on nrITS, nrLSU and mtSSU data sets, similarly as it was done in the Teloschistaceae (see KONDRATYUK et al. 2013, 2014a, b, 2015) was used within this study.

\section{RESULTS}

It should be emphasised that a topology of the phylogenetic tree of the Megasporaceae obtained in the results of our analysis is different from the trees of previous authors. Four more robust clades, i.e. the Agrestia, the Chlorangium, the Sphaerothallia, and the "Circinaria" lacunosa group were resulted additionally to the five genera accepted by Nordin et al. (2010), OWE-LARSSON et al. (2011) and SoHrABI et al. (2013a) within the Megasporaceae. The genera Agrestia J. W. Thomson, Chlorangium Link, and Sphaerothallia Nees ex Eversm., are resurrected within this study (see below).

\section{Separate analyses}

The ITS analysis included 74 sequences of 38 species and a total of 633 positions of which 441 were informative. The LSU analysis included 57 sequences representing 31 species and a total of 787 positions of which 206 were informative, whereas the $12 \mathrm{~S} \mathrm{mtSSU}$ analysis included 71 sequences of 33 species and a total of 826 positions of which 354 were informative. 
Table 1. Material used in this study. Vouchers, their geographical origin, and herbaria where vouchers are deposited are also listed. GenBank accession numbers of the newly obtained sequences are in boldface.

\begin{tabular}{|c|c|c|c|c|}
\hline Taxon name & Country, voucher, reference & ITS & LSU & $\begin{array}{l}12 S \mathrm{SSU} \\
\mathrm{mtDNA}\end{array}$ \\
\hline Agrestia hispida s. 1. & USA, SoHrabi et al. (2011a) & HQ171234 & & \\
\hline Agrestia hispida s. str. & Iran, SoHRABI et al. (2011b) & HQ389197 & & \\
\hline Agrestia hispida s. str. & USA, SoH RABI et al. (2011b) & HQ389198 & & \\
\hline Agrestia hispida s. str. & $\begin{array}{l}\text { Iran, Golestan, Sohrabi } 15099 \\
\text { (hb. M. Sohrabi), SoHRABI et } \\
\text { al. }(2011 a)\end{array}$ & HQ171233 & & \\
\hline Agrestia hispida s. str. & $\begin{array}{l}\text { Iran, Golestan, Sohrabi } 15099 \\
\text { (hb. M. Sohrabi), SoHRABI } e t \\
\text { al. }(2013 a)\end{array}$ & & JQ797503 & JQ797488 \\
\hline Agrestia hispida s. str. & $\begin{array}{c}\text { Russia, Kalmyk, SoHRABI et } \\
\text { al. }(2011 a)\end{array}$ & HQ171235 & & \\
\hline Agrestia hispida s. str. & $\begin{array}{l}\text { Turkey, Candan } 11 \text { (ANES), } \\
\text { Nordin } \text { et al. (2010) }\end{array}$ & & HM060760 & HM060722 \\
\hline Agrestia hispida s. str. & $\begin{array}{l}\text { Turkey, Candan } 11 \text { (ANES), } \\
\text { OwE-LARsSON et al. (2011), } \\
\text { SoHRABI et al. (2013a as Cir- } \\
\quad \text { cinaria hispida s. str.) }\end{array}$ & HQ406806 & & \\
\hline Agrestia hispida s. str. & $\begin{array}{l}\text { Spain, Lumbsch, 2.06.2003 (F), } \\
\text { SCHMITT et al. (2006) }\end{array}$ & & DQ780305 & DQ780273 \\
\hline Agrestia zerovii & $\begin{array}{l}\text { SK A12, Ukraine, Kharkiv } \\
\text { oblast, Dvorychansky district, } \\
\text { "Korobchyno" zakaznik, } \\
\text { 19.06.2013, M. Kryvokhyzhaya } \\
\text { (KW-L), this paper }\end{array}$ & KT456205 & KT456208 & \\
\hline Agrestia zerovii & $\begin{array}{c}\text { SK A12, Ukraine, Kharkiv } \\
\text { oblast, Dvorychansky district, } \\
\text { "Korobchyno" zakaznik, } \\
\text { 19.06.2013, M. Kryvokhyzhaya } \\
\text { (KW-L), KonDRATYU K et al. } \\
\text { (2014c as Circinaria hispida) }\end{array}$ & & & KP059052 \\
\hline Agrestia zerovii & $\begin{array}{l}\text { SK A15, Ukraine, Kharkiv } \\
\text { oblast, Dvorychansky district, } \\
\text { "Korobchyno" zakaznik, } \\
\text { 19.06.2013, M. Kryvokhyzhaya } \\
\text { 2(KW-L), this paper }\end{array}$ & KT456206 & KT456209 & \\
\hline Agrestia zerovii & $\begin{array}{l}\text { SK A15, Ukraine, Kharkiv } \\
\text { oblast, Dvorychansky district, } \\
\text { "Korobchyno" zakaznik, } \\
\text { 19.06.2013, M. Kryvokhyzhaya } \\
\text { 2(KW-L), KonDRATYUK et al. } \\
\text { (2014c as Circinaria hispida) }\end{array}$ & & & KP059053 \\
\hline
\end{tabular}


Table 1. (cont.).

\begin{tabular}{|c|c|c|c|c|}
\hline Taxon name & Country, voucher, reference & ITS & LSU & $\begin{array}{l}12 S \mathrm{SSU} \\
\mathrm{mtDNA}\end{array}$ \\
\hline Aspicilia caesiocinerea & $\begin{array}{l}\text { AFTOL-ID 653, MIADŁI- } \\
\text { KOWSKA et al. (2006) }\end{array}$ & & & DQ986892 \\
\hline Aspicilia caesiocinerea & Sweden, Nordin et al. (2007) & EU057897 & & \\
\hline Aspicilia caesiocinerea & $\begin{array}{l}\text { UK: Wales, Orange } 17594 \\
\text { (NMW) (unpubl.) }\end{array}$ & FJ532372 & & \\
\hline Aspicilia cinerea & $\begin{array}{c}\text { AFTOL-ID 647, SCHMULL et } \\
\text { al. (2011) }\end{array}$ & HQ650637 & & \\
\hline Aspicilia cinerea & $\begin{array}{l}\text { AFTOL-ID 647, MiADEI- } \\
\text { KOWsKA et al. (2006) }\end{array}$ & & DQ986779 & DQ986890 \\
\hline Aspicilia cinerea & $\begin{array}{c}\text { Sweden, Dalarna, Herman- } \\
\text { sson } 13275 \text { (UPS), NoRDIN et } \\
\text { al. }(2007)\end{array}$ & EU057899 & HМ060733 & HM060695 \\
\hline Aspicilia cinerea & $\begin{array}{c}\text { France, Roux } 25015 \text { (MARSSJ), } \\
\text { Roux et al. }(2011)\end{array}$ & JF710311 & & \\
\hline Aspicilia epiglypta & $\begin{array}{l}\text { Sweden, Nordin } 6303 \text { (UPS), } \\
\text { Nordin et al. (2007) }\end{array}$ & EU057907 & & \\
\hline Aspicilia epiglypta & $\begin{array}{l}\text { Sweden, Nordin } 6303 \text { (UPS), } \\
\text { NoRdin et al. (2010) }\end{array}$ & & HM060756 & HM060718 \\
\hline Aspicilia laevata & $\begin{array}{l}\text { Sweden, Tibell } 23659 \text { (UPS), } \\
\text { Nordin et al. (2007) }\end{array}$ & EU057910 & & \\
\hline Aspicilia laevata & $\begin{array}{l}\text { Sweden, Tibell } 23659 \text { (UPS), } \\
\text { Nordin et al. (2010) }\end{array}$ & & HM060730 & HM060692 \\
\hline Circinaria affinis & $\begin{array}{c}\text { Russia: Astrakhan Region, } \\
\text { Kulakov 1408B (M), SoHRABI } \\
\text { et al. }(2011 b)\end{array}$ & HQ389196 & & \\
\hline Circinaria affinis & $\begin{array}{l}\text { Russia: Astrakhan Region, } \\
\text { Kulakov 1408B (M), SoHRABI } \\
\text { et al. }(2013 a)\end{array}$ & & JQ797502 & JQ797492 \\
\hline Circinaria calcarea & $\begin{array}{l}\text { Sweden, Öland, Nordin } 5888 \\
\text { (UPS), NoRDIN et al. (2007) }\end{array}$ & EU057898 & & \\
\hline Circinaria calcarea & $\begin{array}{l}\text { Sweden, Öland, Nordin } 5888 \\
\text { (UPS), NoRDIN et al. (2010) }\end{array}$ & & HM060743 & HM060705 \\
\hline Circinaria calcarea & $\begin{array}{l}\text { Sweden, OwE-LARsson et al. } \\
\text { (2011) }\end{array}$ & HQ406804 & & \\
\hline Circinaria calcarea & $\begin{array}{c}\text { Sweden, Wedin } 6500 \text { (UPS), } \\
\text { WEDIN et al. }(2005)\end{array}$ & & & AY853310 \\
\hline Circinaria calcarea & $\begin{array}{l}\text { Austria(?), Wilfling (GZU), } \\
\text { IvANOVA and HAFELLNER } \\
\text { (2002) }\end{array}$ & AF332109 & & \\
\hline Circinaria calcarea & $\begin{array}{l}\text { AFTOL-ID 1358, MIAD£I- } \\
\text { KOWsKA et al. }(2006)\end{array}$ & & & DQ986876 \\
\hline
\end{tabular}


Table 1. (cont.).

\begin{tabular}{|c|c|c|c|c|}
\hline Taxon name & Country, voucher, reference & ITS & LSU & $\begin{array}{l}12 S S S U \\
\text { mtDNA }\end{array}$ \\
\hline Circinaria cerebroides & $\begin{array}{l}\text { Kyrgyzstan, Innerer Tian-Shan, } \\
\text { Ringel 5138(H), SoHRABI et al. } \\
(2013 a)\end{array}$ & JQ797534 & JQ797506 & JQ797484 \\
\hline Circinaria contorta & $\begin{array}{c}\text { Austria (GZU), Ivanova and } \\
\text { HAFELLNER (2002) }\end{array}$ & AF332108 & & \\
\hline Circinaria desertorum & USA, Nordin et al. (2007) & EU057905 & & \\
\hline Circinaria desertorum & $\begin{array}{c}\text { Russia, OwE-LARSSON } \text { et al. } \\
\text { (2011) }\end{array}$ & HQ406802 & & \\
\hline Circinaria desertorum & Russia, Nordin et al. (2010) & & & HM060689 \\
\hline Circinaria digitata & $\begin{array}{c}\text { Kyrgyzstan, SoHRABI et al. } \\
(2011 a)\end{array}$ & HQ171230 & & \\
\hline Circinaria digitata & $\begin{array}{l}\text { Kyrgyzstan, SoHRABI et al. } \\
\qquad(2011 a)\end{array}$ & HQ171236 & & \\
\hline Circinaria elmorei & $\begin{array}{l}\text { Russia, Owe-Larsson } 9814 \\
\text { (UPS), Nordin et al. (2010) }\end{array}$ & HQ406802 & HM060727 & HM060689 \\
\hline Circinaria cf. elmorei & $\begin{array}{c}\text { Ukraine: Crimea, SoHRABI et } \\
\text { al. }(2013 a)\end{array}$ & JQ797551 & & \\
\hline Circinaria cf. elmorei & Iran, Sohrabi et al. (2013a) & JQ797542 & & \\
\hline Circinaria cf. elmorei & Iran, SoHRABI et al. (2013a) & JQ797526 & & \\
\hline Circinaria cf. elmorei & Iran, SoHRABI et al. (2013a) & JQ797558 & & \\
\hline Circinaria emiliae & $\begin{array}{c}\text { Kazakhstan, Atyrau, Kulakov } \\
3702 \text { (UPS), SoH RABI et al. } \\
(2013 a)\end{array}$ & JQ797512 & & \\
\hline Circinaria emiliae & $\begin{array}{c}\text { Kazakhstan, Atyrau, Kulakov } \\
3702 \text { (UPS), NordiN et al. } \\
\text { (2010) }\end{array}$ & & HM060728 & HM060690 \\
\hline Circinaria emiliae & $\begin{array}{l}\text { Kazakhstan, Atyrau, Kulakov } \\
\text { 3702B (UPS), SoHRABI et al. } \\
(2013 a)\end{array}$ & JQ797513 & & \\
\hline Circinaria emiliae & $\begin{array}{c}\text { Kazakhstan, Atyrau, Kulakov } \\
3798 \text { (UPS), Nordin et al. } \\
\text { (2010) }\end{array}$ & & HM060729 & HM060691 \\
\hline Circinaria fruticulosa & $\begin{array}{c}\text { Ukraine: Crimea, SOHRABI } e t \\
\text { al. }(2013 a)\end{array}$ & JQ797555 & & \\
\hline Circinaria fruticulosa & Turkey, SoHraBi et al. (2013a) & JQ797535 & & \\
\hline Circinaria fruticulosa & $\begin{array}{c}\text { Kazakhstan, Tarbagatai, } \\
\text { Lange } 5186(\mathrm{H}), \text { SoHRABI } e t \\
\text { al. }(2013 b)\end{array}$ & HQ171228 & JQ797505 & JQ797486 \\
\hline Circinaria gibbosa & $\begin{array}{l}\text { Sweden, Uppland, Nordin } 5878 \\
\text { (UPS), Nordin et al. (2007) }\end{array}$ & EU057908 & & \\
\hline Circinaria gibbosa & $\begin{array}{l}\text { Sweden, Uppland, Nordin } 5878 \\
\text { (UPS), NoRDIN et al. (2010) }\end{array}$ & & HM060740 & HM060702 \\
\hline
\end{tabular}


Table 1. (cont.).

\begin{tabular}{|c|c|c|c|c|}
\hline Taxon name & Country, voucher, reference & ITS & LSU & $\begin{array}{l}12 S \mathrm{SSU} \\
\mathrm{mtDNA}\end{array}$ \\
\hline Circinaria jussuffii & $\begin{array}{l}\text { Morocco, SoHrabI et al. } \\
\qquad(2013 a)\end{array}$ & JQ797521 & & \\
\hline Circinaria jussuffii & $\begin{array}{l}\text { Algeria, Esnault } 2033 \text { (GZU), } \\
\text { SoHRABI et al. }(2013 a)\end{array}$ & JQ797518 & JQ797495 & JQ797489 \\
\hline Circinaria lacunosa & $\begin{array}{l}\text { Kazakhstan, SoHRABI et al. } \\
\qquad(2013 a)\end{array}$ & JQ797520 & & \\
\hline Circinaria lacunosa & $\begin{array}{l}\text { China, Xinjiang, Abbas } 940003 \\
\text { (H), SoHrABI et al. (2013a) }\end{array}$ & JQ797517 & JQ797494 & JQ797490 \\
\hline Circinaria leprosescens & $\begin{array}{l}\text { Sweden, Uppland, Nordin } 5906 \\
\text { (UPS), Nordin et al. (2007) }\end{array}$ & EU057911 & & \\
\hline Circinaria leprosescens & $\begin{array}{l}\text { Sweden, Uppland, Nordin } 5906 \\
\text { (UPS), Nordin et al. (2010) }\end{array}$ & & HM060749 & HM060711 \\
\hline Circinaria rogeri & USA, SOHRABI et al. (2011a) & HQ171231 & & \\
\hline Circinaria rogeri & USA, SoHraBi et al. (2011a) & HQ171232 & & \\
\hline Circinaria rostamii & $\begin{array}{l}\text { Iran, East Azerbaijan, Sohrabi } \\
10212 \text { (IRAN), SoHRABI et al. } \\
\text { (2013a) }\end{array}$ & JQ797538 & JQ797507 & JQ797491 \\
\hline Chlorangium alpicola & $\begin{array}{c}\text { Kyrgyzstan, SOHRABI et al. } \\
\qquad(2013 a)\end{array}$ & JQ797556 & & \\
\hline Chlorangium alpicola & $\begin{array}{c}\text { Kyrgyzstan, SOHRABI et al. } \\
(2013 a)\end{array}$ & JQ797552 & & \\
\hline Chlorangium alpicola & $\begin{array}{l}\text { Kyrgyzstan, SoH RABI et al. } \\
\qquad(2013 a)\end{array}$ & JQ797524 & & \\
\hline Chlorangium alpicola & $\begin{array}{l}\text { Kyrgyzstan, Ringel 5241, } \\
\text { SoHRABI et al. }(2013 a)\end{array}$ & JQ797554 & & \\
\hline $\begin{array}{l}\text { Chlorangium } \\
\text { aschabadense }\end{array}$ & $\begin{array}{l}\text { Turkmenistan, SOHRABI et al. } \\
\qquad(2013 a)\end{array}$ & JQ797519 & & \\
\hline $\begin{array}{l}\text { Chlorangium } \\
\text { aschabadense }\end{array}$ & $\begin{array}{l}\text { Turkmenistan, SoHRABI et al. } \\
\qquad(2010 a)\end{array}$ & GU289916 & & \\
\hline $\begin{array}{l}\text { Chlorangium cf. aspe- } \\
\text { rum }\end{array}$ & $\begin{array}{l}\text { Russia, Astrakhan region, } \\
\text { SoHrABI et al. (2013a) }\end{array}$ & JQ797531 & & \\
\hline Chlorangium gyrosum & Spain, SOHRABI et al. (unpubl.) & JX306734 & & \\
\hline Chlorangium gyrosum & Iran, SoHRABI et al. (2013a) & NR_120106 & & \\
\hline Chlorangium gyrosum & $\begin{array}{l}\text { Iran, East Azerbaijan, Sohrabi } \\
10085 \text { (hb. M. Sohrabi), } \\
\text { SoHRABI et al. (2013a) }\end{array}$ & JQ797540 & JQ797504 & \\
\hline Chlorangium gyrosum & Iran, SoHRABI et al. (2013a) & JQ797539 & & \\
\hline Chlorangium gyrosum & Spain, SoHRABI et al. (2013a) & JQ797557 & & \\
\hline Chlorangium gyrosum & $\begin{array}{l}\text { Iran, East Azerbaijan, Sohrabi } \\
\text { 10401A (hb. M. Sohrabi), } \\
\text { SoHrABI et al. (2013a) }\end{array}$ & JQ797528 & & JQ797487 \\
\hline
\end{tabular}


Table 1. (cont.).

\begin{tabular}{|c|c|c|c|c|}
\hline Taxon name & Country, voucher, reference & ITS & LSU & $\begin{array}{l}12 S \text { SSU } \\
\text { mtDNA }\end{array}$ \\
\hline $\begin{array}{l}\text { Chlorangium sphaeroth- } \\
\text { allinum }\end{array}$ & $\begin{array}{l}\text { Iran, Semnan, Sohrabi } 9369 \\
\text { (hb. M. Sohrabi), SoH RABI et } \\
\text { al. (2013a) }\end{array}$ & JQ797545 & JQ797508 & JQ797476 \\
\hline $\begin{array}{l}\text { Chlorangium sphaero- } \\
\text { thallinum }\end{array}$ & Iran, SOHRABI et al. (2013a) & JQ797537 & & \\
\hline $\begin{array}{l}\text { Chlorangium sphaero- } \\
\text { thallinum }\end{array}$ & Iran, SoHRABi et al. (2013a) & JQ797536 & & \\
\hline $\begin{array}{l}\text { Chlorangium sphaero- } \\
\text { thallinum }\end{array}$ & Iran, SoHRABi et al. (2013a) & JQ797543 & & \\
\hline $\begin{array}{l}\text { Chlorangium sphaero- } \\
\text { thallinum }\end{array}$ & $\begin{array}{c}\text { Armenia, SoHrabi } e t a l . \\
(2013 a)\end{array}$ & JQ797525 & & \\
\hline Lobothallia alphoplaca & $\begin{array}{l}\text { USA, Leavitt } 447 \text { (BRY), } \\
\text { SOH RABI et al. (2013b) }\end{array}$ & JX306737 & & \\
\hline Lobothallia alphoplaca & USA, SoHrABI et al. (2013b) & JX306738 & & \\
\hline Lobothallia alphoplaca & USA, SoHRABI et al. (2013b) & JX306739 & & \\
\hline Lobothallia alphoplaca & $\begin{array}{c}\text { China, SDNU } 20117646, \mathrm{KoU} \\
\text { et al. (2013) }\end{array}$ & JX476025 & & \\
\hline Lobothallia alphoplaca & $\begin{array}{l}\text { SK A20, Ukraine, Donetzk ob- } \\
\text { last, "Kamjani Mogyly" zapo- } \\
\text { vidnyk, near the stream, } 131 \mathrm{~m} \\
\text { alt, 13.05.2011, Nadeina et al. } \\
\text { [ex KW-L 68283], this paper }\end{array}$ & KT456207 & KT456210 & KT456211 \\
\hline Lobothallia melanaspis & $\begin{array}{l}\text { Norway, VALADBEIGI et al. } \\
\text { (2011) }\end{array}$ & JF825524 & & \\
\hline Lobothallia melanaspis & $\begin{array}{l}\text { Sweden, Jämtland, Nordin } 6622 \\
\text { (UPS), NoRDIN et al. (2011) }\end{array}$ & HQ259272 & & \\
\hline Lobothallia melanaspis & $\begin{array}{l}\text { Sweden, Jämtland, Nordin } 6622 \\
\text { (UPS), Nordin et al. (2010) }\end{array}$ & & HM060726 & HM060688 \\
\hline Lobothallia radiosa & Sweden, Roux et al. (2011) & JF703124 & & \\
\hline Lobothallia radiosa & $\begin{array}{l}\text { Switzerland, Schmitt et al. } \\
\text { (2006) }\end{array}$ & & DQ780306 & DQ780274 \\
\hline Lobothallia recedens & $\begin{array}{l}\text { Sweden, Dalarna, Nordin } 6582 \\
\text { (UPS), Nordin et al. (2010) }\end{array}$ & & HМ060762 & HM060724 \\
\hline Megaspora verrucosa & $\begin{array}{c}\text { Austria, 1996, Trinkaus } \\
\text { (GZU), IVANOVA and } \\
\text { HAFELLNER (2002) }\end{array}$ & AF332121 & & \\
\hline Megaspora verrucosa & $\begin{array}{c}\text { Austria(?), Hafellner } 48544 \text { \& } \\
\text { Ivanova (GZU), IVANOVA and } \\
\text { HAFELLNER (2002) }\end{array}$ & AF332122 & & \\
\hline Megaspora verrucosa & USA, SoHraBi et al. (2013b) & KC667053 & & \\
\hline Megaspora verrucosa & $\begin{array}{l}\text { Sweden, Jämtland, Nordin } 6495 \\
\text { (UPS), Nordin et al. (2010) }\end{array}$ & & HM060725 & HM060687 \\
\hline
\end{tabular}


Table 1. (cont.).

\begin{tabular}{|c|c|c|c|c|}
\hline Taxon name & Country, voucher, reference & ITS & LSU & $\begin{array}{l}12 S \text { SSU } \\
\text { mtDNA }\end{array}$ \\
\hline Megaspora verrucosa & $\begin{array}{c}\text { Iran, East Azerbaijan, Sipman } \\
55434 \text { (B), SoHRABI et al. } \\
(2013 a)\end{array}$ & & JQ797498 & JQ797483 \\
\hline Megaspora verrucosa & $\begin{array}{c}\text { Turkey, Prov. Çorum, Kinali- } \\
\text { oglu } 1679 \text { (B), SoHRABI et al. } \\
(2013 a)\end{array}$ & & JQ797497 & JQ797482 \\
\hline Oxneria alfredi & $\begin{array}{c}\text { FNM 152, Russia, FEDOREN- } \\
\text { Ko et al. (2009) }\end{array}$ & EU681344 & & EU680932 \\
\hline Oxneria buculica & $\begin{array}{c}\text { FNM 199, Russia, FEDOREN- } \\
\text { Ko et al. (2009) }\end{array}$ & EU681346 & & EU680931 \\
\hline Oxneria buculica & $\begin{array}{c}\text { USA, Søchting 9566, C ARUP } \\
\text { et al. (2013) }\end{array}$ & & KC179279 & \\
\hline Oxneria ulophyllodes & $\begin{array}{l}\text { FNM 198, FEDORENKO et al. } \\
(2009)\end{array}$ & EU681342 & & EU680930 \\
\hline Oxneria ulophyllodes & $\begin{array}{l}\text { USA: Wetmore } 80270, \mathrm{LD} \\
\text { ARUP et al. (2013) }\end{array}$ & & KC179283 & \\
\hline Sagedia mastrucata & $\begin{array}{c}\text { Sweden, Lycksele Lappmark, } \\
\text { Nordin } 5481 \text { (UPS), NoRDIN } \\
\text { et al. (2007) }\end{array}$ & EU057914 & & \\
\hline Sagedia mastrucata & $\begin{array}{c}\text { Sweden, Lycksele Lappmark, } \\
\text { Nordin } 5481 \text { (UPS), NordiN } \\
\text { et al. (2010) }\end{array}$ & & HM060737 & HM060699 \\
\hline Sagedia mastrucata & $\begin{array}{l}\text { Norway, Troms, Nordin } 5708 \\
\text { (UPS), NoRDin et al. (2007) }\end{array}$ & EU057913 & & \\
\hline Sagedia mastrucata & $\begin{array}{l}\text { Norway, Troms, Nordin } 5708 \\
\text { (UPS), NoRDIN et al. (2010) }\end{array}$ & & HМ060736 & HM060698 \\
\hline Sagedia simoënsis & $\begin{array}{c}\text { Norway, Troms, Owe-Larsson } \\
9000 \text { (UPS), Nordin et al. } \\
(2010)\end{array}$ & & HM060739 & HМ060701 \\
\hline Sagedia zonata & $\begin{array}{l}\text { Sweden, Nordin } 6006 \text { (UPS), } \\
\text { Nordin et al. (2007) }\end{array}$ & EU057952 & & \\
\hline Sagedia zonata & $\begin{array}{c}\text { Sweden, Nordin } 5949 \text { (UPS), } \\
\text { NoRDin et al. (2007) }\end{array}$ & EU057953 & & \\
\hline Sagedia zonata & $\begin{array}{c}\text { Norway, Troms, Owe-Larsson } \\
8942 \text { (UPS), Nordin et al. } \\
(2010)\end{array}$ & & HM060738 & HM060700 \\
\hline Sphaerothallia esculenta & $\begin{array}{l}\text { Russia, Astrakhan region, } \\
\text { SoHRABI et al. (2013a) }\end{array}$ & JQ797511 & & \\
\hline Sphaerothallia esculenta & $\begin{array}{l}\text { Russia, Astrakhan Region, } \\
\text { Owe-Larsson } 9796 \text { (UPS), } \\
\text { SoHRABI et al. (2013a) }\end{array}$ & & JQ797493 & JQ797485 \\
\hline
\end{tabular}


The new species Agrestia zerovii, forms as a strongly supported clade in all separate analyses with the highest level of bootstrap support.

However, based on ITS analysis Agrestia zerovii forms a robust monophyletic clade within the Agrestia clade together with specimens of Agrestia hispida s. str. with GenBank accession numbers HQ389197 and HQ389198 (data not shown). The specimen of Chlorangium asperum (Mereschk.) S. Y. Kondr., A. B. Gromakova et Khodos. is a member of the Chlorangium clade with C. jussuffi (Link) Link, C. sphaerothallinum (J. Steiner) S. Y. Kondr., A. B. Gromakova et Khodos., C. aschabadense (J. Steiner) S. Y. Kondr., A. B. Gromakova et Khodos., and C. alpicola (Elenkin) S. Y. Kondr., A. B. Gromakova et Khodos.

Based on LSU analysis Agrestia zerovii forms as robust monophyletic branch a weakly supported clade with specimens of Agrestia hispida s. str. with GenBank accession numbers DQ780305 and HM060760 (data not shown). Unfortunately, LSU data are still missing for Chlorangium asperum.

According to the mtSSU analysis all specimens of Agrestia zerovii, Agrestia hispida s. str., and Agrestia hispida s. 1., as well as specimen of Chlorangium asperum are rather different and they do not form a separate clade (data not shown).

\section{Combined analysis}

The alternative combined analysis based on nuclear ITS, LSU and 12S mtSSU data sets included 67 specimens of 29 species and a total of 2,084 positions of which 1,050 were informative.

The combined phylogenetic analysis based on ITS and LSU nrDNA, as well as $12 \mathrm{~S}$ SSU mtDNA sequences strongly supports the proposal that the new species Agrestia zerovii is a member of the genus Agrestia (Fig. 1). Agrestia zerovii appears as a sister group to the other Agrestia hispida s. str. and Agrestia hispida s. 1. specimens based on data so far available in GenBank. The genus Agrestia together with the genera Sphaerothallia Nees ex Eversm., Chlorangium Link, as well as the "Circinaria" lacunosa group form a weakly supported clade (Fig. 1). The specimen of Chlorangium asperum similarly to the nrITS analysis is a member of the Chlorangium clade.

\section{DISCUSSION}

Our data on the number ofgeneric clades/brancheswithin the Megasporaceae are, however, in conflict with Nordin et al. (2010), OWE-LARsson et al. (2011), and Sohrabi et al. (2013a), who accepted the division of the Megasporaceae into the following five genera, i.e. Aspicilia, Circinaria, Lobothallia, Megaspora, and Sagedia using a combined data set of nrLSU and mtSSU. 


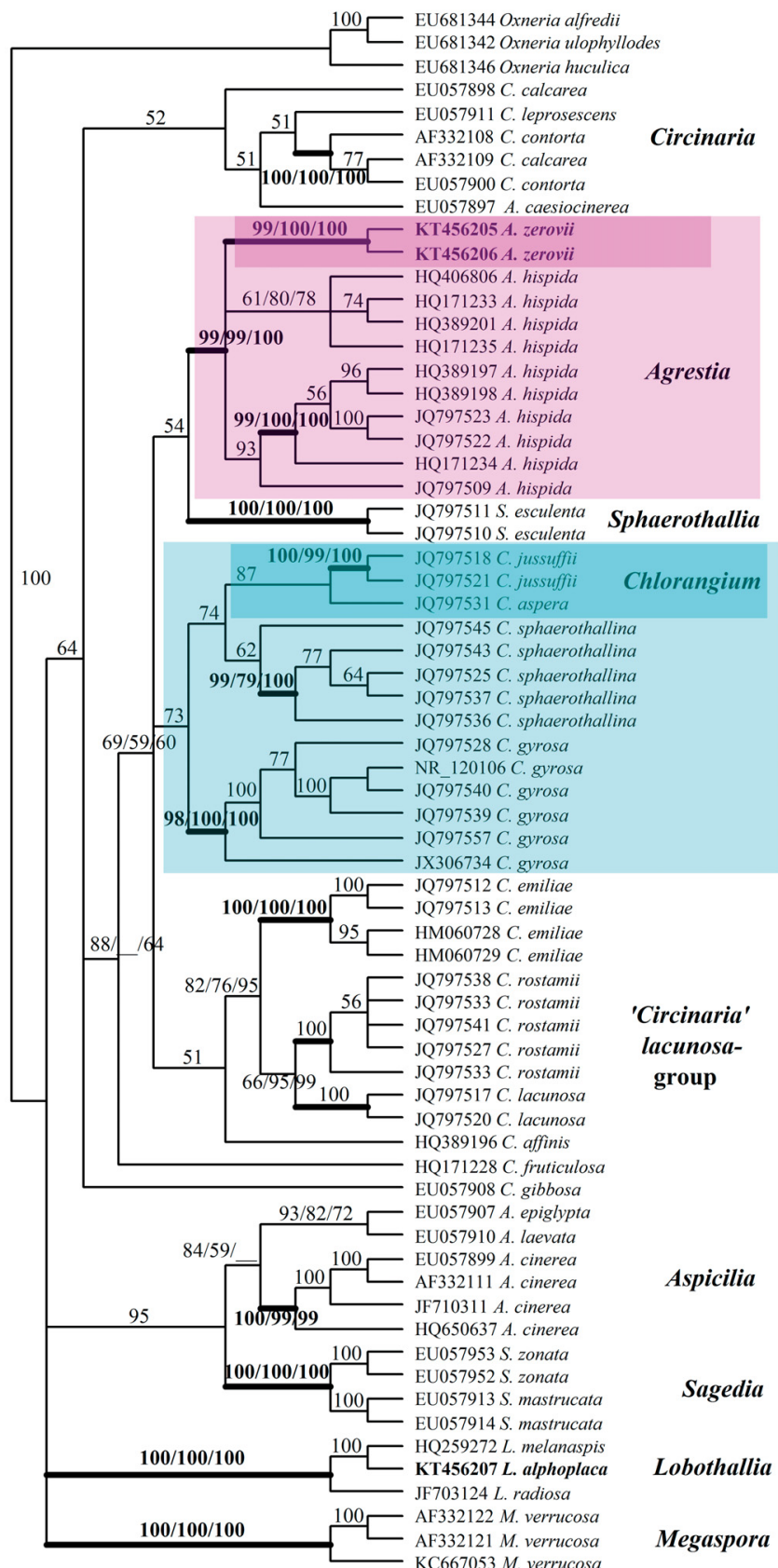

Fig. 1. The combined phylogenetic tree of the Megasporaceae based on nrITS, nrLSU and mtSSU data set (data of MP. ME and ML methods are shown if branches have had support in all the cases, otherwise only data of MP analysis are given). 
The Circinaria s. str. branch

The genus Circinaria Link resurrected by Nordin et al. (2010) and OwELARSSON et al. (2011) has very low support according to our alternative combined phylogenetic analysis based on the nrITS, nrLSU and mtSSU data sets, and probably can be accepted for a very narrow species group, i.e.: C. contorta group s. str., including only C. contorta (Hoffm.) A. Nordin, S. Savić et Tibell, C. leprosescens (Sandst.) A. Nordin, S. Savić et Tibell, C. caesiocinerea (Nyl. ex Malbr.) A. Nordin, S. Savić et Tibell, and C. calcarea (L.) A. Nordin, S. Savić et Tibell (Fig. 1). It should be mentioned that molecular data of one voucher specimen is still missing for $C$. contorta, the type species of this genus. Nordin et al. (2010) and SoHRABI et al. (2013a) provided nrITS sequences on one side and nrLSU and $\mathrm{mtSSU}$ sequences on another side from different voucher specimens. However, the rather weak support of the Circinaria s. str. branch in the phylogenetic tree of the Megasporaceae (Fig. 1) illustrates that C. contorta is still a complex taxon or the identification of some voucher specimens was incorrect.

The Sphaerothallia s. 1. clade

The other species group included by previous authors into the genus Circinaria s. 1. and forming separate group from the Circinaria s. str. clade, hereafter the Sphaerothallia s. l. clade, which, however, has very weak support (Fig. 1). The Sphaerothallia s. 1. clade includes four robust branches, i.e.: the Agrestia, the Chlorangium, the Sphaerothallia s. str. and the "Circinaria" lacunosa group.

\section{The Agrestia branch}

Our data on the Agrestia hispida group are, however, in conflict with SoH RABI et al. (2013a), who proposed that this complex belongs to the genus Sphaerothallia (as S. hispida (Mereschk.) Follmann et A. Crespo). All specimens of Agrestia hispida s. str., as well as Agrestia hispida s. 1. form a separate robust monophyletic branch, which is sister to the Sphaerothallia and the Chlorangium branches, as well as to the "Circinaria" lacunosa group within the Sphaerothallia s. 1. clade.

For this reason Agrestia J. W. Thomson (THOMson 1961) might be assumed to be an appropriate generic name for this monophyletic clade if the type species, Agrestia cyphellata J. W. Thomson, a terricolous lichen from Canada and the USA, belongs to this clade. The status of this species needs urgent verification by molecular data.

After Sohrabi et al. (2013a) "Circinaria" elmorei (E. D. Rudolph) OweLarss., "Circinaria" sp. 3, "Circinaria" rogeri (Sohrabi) Sohrabi, and "Circinaria" digitata (Sohrabi et Litterski) Sohrabi are closely related to the Agrestia hispida complex based on the nrITS data set. However "Circinaria" elmorei was not in- 
cluded in our combined data (see below), and "Circinaria" rogeri and "Circinaria" digitata for which data on nrLSU and mtSSU are still missing in GenBank were also excluded from our combined analysis. "Circinaria" elmorei was not included in our combined phylogenetic analysis since there are contradictive data on this species in GenBank. According to nrITS "Circinaria" elmorei is positioned in several branches, while data on nrLSU and mtSSU sequences originate from only one voucher which is not the type of this species. Unidentified and undescribed taxa are also excluded from our analysis.

\section{The Sphaerothallia branch}

The genus Sphaerothallia is assumed by SoHRA BI et al. (2013a) to be a probably appropriate generic name for the rather large group of spherothalloid lichens (sensu SoHRABi et al. 2013a). However, our data indicate that the genus can be used for a very narrow group including so far only the type species $S$. esculenta (Pall.) Reichardt, which has the highest level of support as a separate branch in the phylogenetic tree of the family (Fig. 1). According to SoHRABI et al. $(2013 a)$ the Sphaerothallia s. str. clade includes also "Circinaria" elmorei s. 1. using nrITS data set. However, "Circinaria" elmorei as it is emphasised above was not included in our combined phylogenetic analysis.

Our analysis demonstrates that another "Circinaria" species, "Circinaria" emiliae does not belong to the Sphaerothallia s. str. branch in contrast to the data by Sohrabi et al. (2013a) (Fig. 1).

Furthermore "Circinaria" sp. 2 according to SOHRABI et al. (2013a) is also closely related to this branch. However, unidentified and undescribed taxa are excluded from our analysis.

\section{The Chlorangium branch}

The Chlorangium clade includes the type species $C$. jussuffi (Link) Link, as well as $C$. alpicola, $C$. aschabadense, and $C$. asperum. The status of Chlorangium gyrosum (Sohrabi, Sipman, V. John et V. J. Rico) S. Y. Kondr., A. B. Gromakova et Khodos. and C. sphaerothallinum (J. Steiner) S. Y. Kondr., A. B. Gromakova et Khodos. in this branch is the most questionable since this clade has rather weak support. These species may belong to separate monophyletic clades.

Based on nrITS data set (both by SoHRABI et al. (2013a) and by our nrITS analysis) Chlorangium alpicola belongs to the Chlorangium clade, however, it was not included in the combined analysis since nrLSU and mtSSU data are still missing for this taxon. Based on nrITS data set "Circinaria" fruticulosa (Eversm.) Sohrabi is in sister position to Chlorangium gyrosum with very weak level of support (SoнRABi et al. 2013a). However, "Circinaria" fruticulosa was excluded from 
our analysis because its mtSSU sequence data are very different from all other members of the Megasporaceae. The data on mtSSU of "Circinaria" fruticulosa need to be confirmed by further voucher specimens.

\section{The "Circinaria" lacunosa group branch}

The "Circinaria" lacunosa group includes "C." lacunosa (Mereschk.) Sohrabi, "C." rostamii Sohrabi, and " C." emiliae (Tomin) A. Nordin, S. Savić et Tibell. The branch shows the highest level of support for all the species each sampled from four to five voucher specimens. According to the nrITS data set published by Sohrabi et al. (2013a), this group includes also "Circinaria" affinis (Eversm.) Sohrabi. However, based on our data "C." affinis, for which there is only one voucher sequence with ITS and LSU nrDNA and 12S SSU mtDNA available in GenBank, falls out of the whole Sphaerothallia s. 1. clade.

After SoHrabi et al. (2013a) this branch includes also "Circinaria" cerebroides (Mereschk.) Sohrabi based on nrITS data set. However, this species was excluded from our combined analysis because its nrLSU and mtSSU data are incomplete and very different from other taxa included in our combined matrix.

Our data support the data of previous authors (SoHRABI et al. 2013a) that the Aspicilia epiglypta group (including $A$. epiglypta (Norrl. ex Nyl.) Hue, $A$. indissimilis (H. Magn.) Räsänen, and $A$. laevata (Ach.) Arnold) has very low support together with Aspicilia s. str. (i.e. Aspicilia cinerea group). So the status of the Aspicilia epiglypta group requires further investigations.

Thus, four more robust monophyletic branches, i.e. the Agrestia, the Chlorangium, the Sphaerothallia, and the "Circinaria" lacunosa group branches within the Sphaerothallia s. l. clade, having very weak support and located in separate place from the Circinaria s. str. clade, are shown additionally to five genera accepted by NorDIN et al. (2010), Owe-LARsson et al. (2011) and Sohrabi et al. (2013a) within the Megasporaceae (Aspicilia, Circinaria, Lobothallia, Megaspora and Sagedia).

Consequently, the genera Agrestia J. W. Thomson, Chlorangium Link, and Sphaerothallia Nees ex Eversm. are resurrected within this study.

\section{Taxon description}

Agrestia zerovii S. Y. Kondr., A. B. Gromakova et Khodos., spec. nova

(Figs 2-4)

MycoBank no.: MB 813878.

Similar to Agrestia hispida s. str., but differs in having well-developed, horizontally orientated, very thick thalline lobes often forming distinct crust of the central portion of thallus, in the lack of blackish tips of the erect secondary branchlets, as well as deviates in the nrDNA ITS region. 
Type: Ukraine, Kharkiv oblast (= region), Dvorichansky district, in the vicinity of Dvoricha-

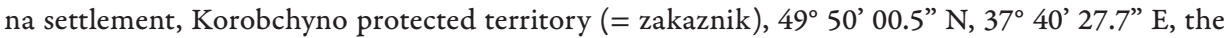
upper part of the slope, to $\mathrm{W}$ from the road, below of plantation, leg. Gromakova, A. B., s.n., 27.05.2012, (holotype: KW-L 70479); the same locality (isotypes: KW-L 70480, KHER, CWU).

Thallus subfruticose, erratic (sensu BÜDEL and Wessels (1986), i.e. the facultatively unattached lichen), $2-3(-4) \mathrm{cm}$ in diam./across and $1.5-3(-4)[-8]$ mm thick; bushy, more or less Cladonia-like thallus with abundant erect secondary branchlets or mainly "horizontal crusts" of densely compressed main lobes and scarce erect secondary branchlets, grey to greenish-grey if freshly collected especially in wet conditions; consisting of two morphologically different types of thalline lobes, i.e. the main lobes very thick, $(1.5-) 2-3(-3.5) \mathrm{mm}$ wide and to 7-10(-14) mm long, massive, mainly horizontally orientated, often somewhat compressed or deformed, infrequently regularly cylindrical, often densely pressed to each other and form thick "horizontal crust" of (3-)7-10(-12) mm across with numerous erect secondary lobules.

Secondary lobules (1-)3-6(-8) mm long, ranging from very thin $(0.2-0.3$ $\mathrm{mm}$ diam.) to rather thick $(0.5-) 0.7-1.2(-1.5) \mathrm{mm}$ diam.) at the basis and gradually becoming thinner towards the tips, mainly erect, usually regularly cylindrical, concolorous along the whole length (not blackish towards the tips); sometimes secondary lobules branched and secondary branchlets 1-2 mm long and ca $0.5 \mathrm{~mm}$ in diam. at the basis and becoming thinner towards the tips present; pseudocyphellae regularly rounded up to $0.2-0.3 \mathrm{~mm}$ in diam., white, sometimes quite distinct. Apothecia unknown. Conidia not seen.

Chemistry: All spot-tests $(\mathrm{K}, \mathrm{C}, \mathrm{KC}, \mathrm{CK}, \mathrm{P})$ negative both in the cortex and medulla.

Ecology: The species grows together with Collema tenax (Sw.) Ach. var. tenax, C. tenax var. ceranoides (Borrer) Degel., C. crispum (Huds.) Weber ex F. H. Wigg., Endocarpon pusillum Hedw., Megaspora verrucosa (Ach.) Arcadia et A. Nordin, Thrombium epigaeum (Pers.) Wallr. on lime rich soil in arid steppe or steppe-like habitats. Vagrant forms accumulate in wind-deposited drifts.

The following plants accompanying Agrestia zerovii were registered: Androsace koso-poljanskii Ovcz., Artemisia hololeuca M. Bieb. ex Besser, Asperula tephrocarpa Czern. ex M. Pop. et Chrshan., Astragalus albicaulis DC., Hedysarum grandiflorum Pall., Hyssopus cretaceus Dubjan., Linaria cretacea Fisch. ex Spreng., Linum ucranicum (Griseb. ex Planch.) Czern., Pimpinella titanophila Woronow, Polygala cretacea Kotov, Thymus calcareus Klokov et Des.-Shost. (see also Groma Kova 2013).

Two different morphotypes were observed in the field conditions of the type locality. Bushy, more or less Cladonia-like thallus with abundant, erect secondary branchlets are easily observable in the open areas, while mainly "horizontal crusts" 

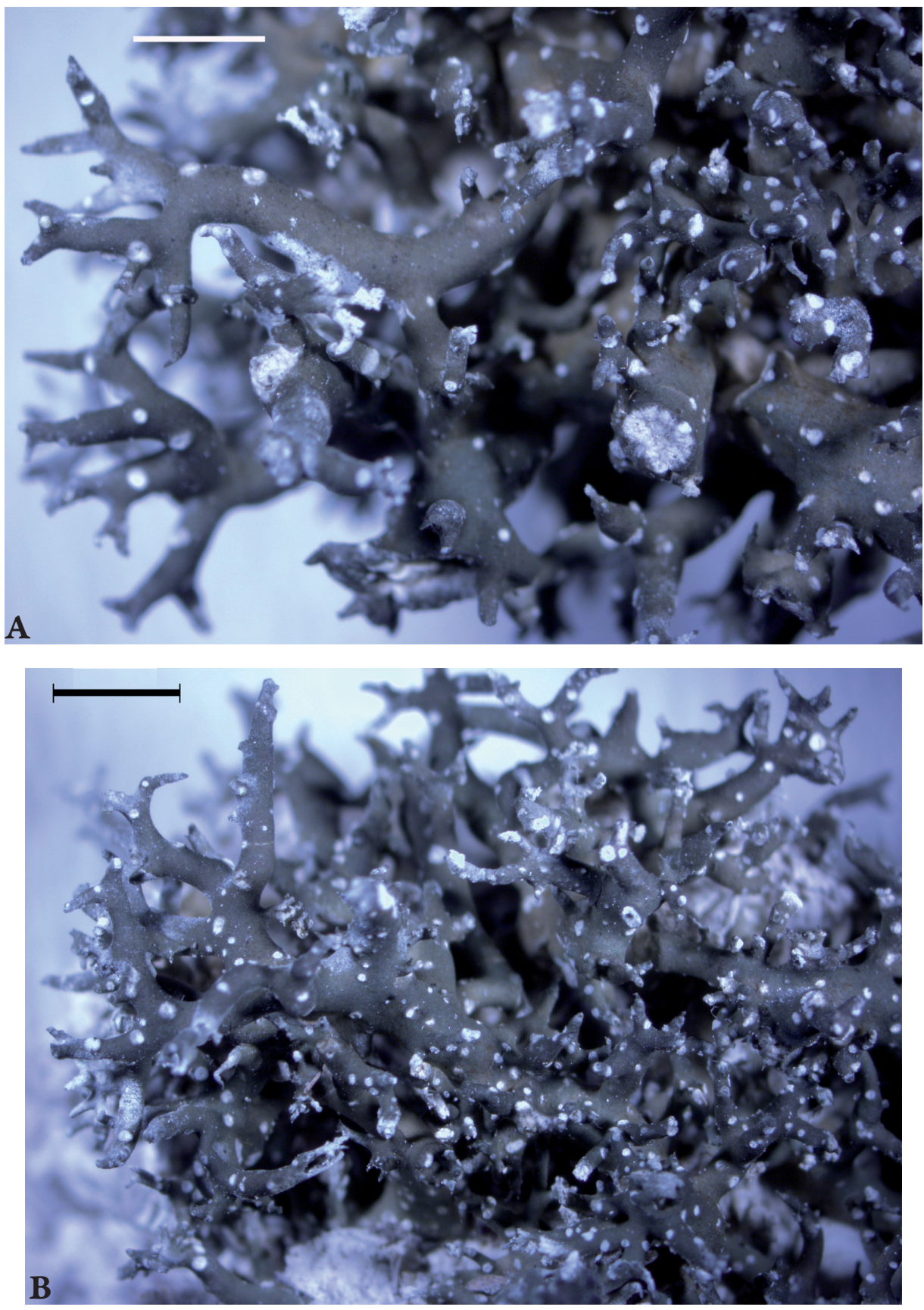

Fig. 2. Agrestia zerovii (holotype), general habit. Scale: $\mathrm{A}=2 \mathrm{~mm}, \mathrm{~B}=3 \mathrm{~mm}$. 

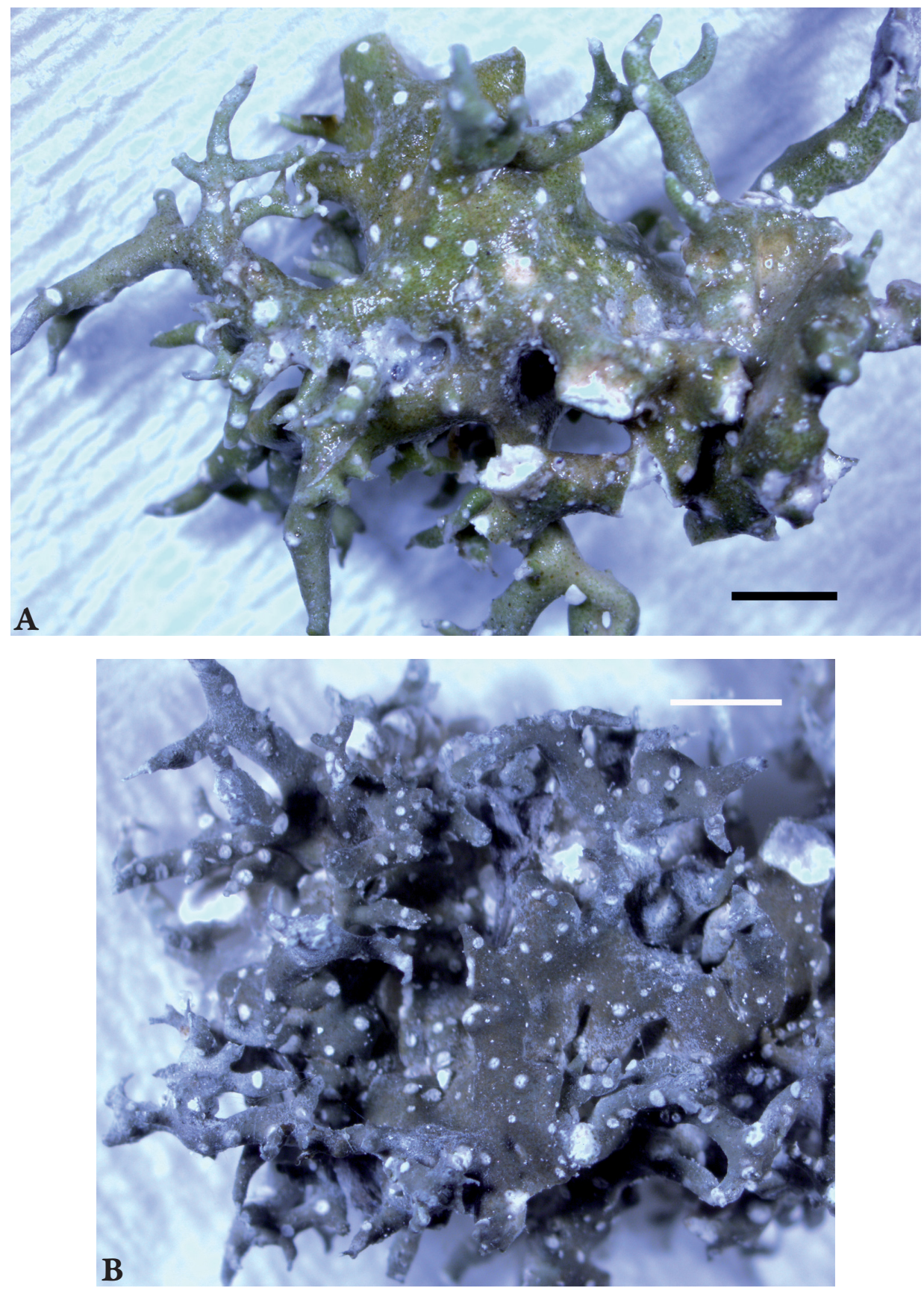

Fig. 3. Agrestia zerovii (holotype), enlarged "horizontal crust" of two different thalli, $\mathrm{A}=$ after wetting, $\mathrm{B}=$ in dry conditions. Scale: $\mathrm{A}$ and $\mathrm{B}=2 \mathrm{~mm}$. 
of densely compressed main lobes and scarce erect secondary branchlets were observed under the crown layer of the endemic shrub species, Thymus calcareus.

Etymology: It is named after Dmytro K. Zerov (1895-1971) (Kyiv, Ukraine, $\mathrm{KW}-\mathrm{B}$ ) in honour of the 120th anniversary of his birthday. He was a well-known Ukrainian bryologist, palaeobotanist, and specialist of the phylogeny of nonvascular (= lower) plants, and the founder of the Kyiv bryological and Ukrainian palaeobotanical scientific schools.

Distribution: In contrast to Agrestia hispida, which is a widely distributed steppe element in temperate and subtropical, semi-arid regions of the Northern Hemisphere from Italy to the Russian part of the Caspian Sea coast, the TianShan Mts in Kyrgyzstan and Iran (Andreeva 1987, Kulakov 2002, 2003, HAFEllner et al. 2004, SEAwARd et al. 2008) and North America (OWE-LARSson et al. 2007), A. zerovii is so far known only from the type locality, where it was observed in the 1940s.

It is important to emphasise that Agrestia zerovii was first recorded/collected from locus classicus by a known Ukrainian bryologist, Dr Anna F. Bachurina, one of the students of Dmytro K. Zerov. The Ukrainian localities of Agrestia hispi$d a$ recorded by MERESCHKOWS KY (1911), OXNER (2010) and other colleagues require revision since some of them may belong to $A$. zerovii too.

Taxonomic notes: Though Agrestia zerovii is more or less similar to $A$. hispi$d a$ s. str. it differs in having much thinner $(1.3-3(-4) \mathrm{mm}$ thick vs. 5-20 mm tall?) thalline tufts, two morphologically different types of thalline lobes, welldeveloped, horizontally orientated, much thicker $(2-3(-3.5) \mathrm{mm}$ diam. vs. (0.30.5-1.5(-2) mm diam.) main lobes, often distinct "horizontal portion" or flattened crust of thallus consisting of interwoven/or to each other pressed flattened main lobes of (3-)7-10(-12) mm across, in the lack of blackish tips of the erect secondary branchlets. Finally, it has different sequence of the nrDNA ITS region.

Agrestia zerovii is positioned in a branch separate from the specimens of Agrestia hispida s. str. in the combined phylogenetic analysis based on ITS and LSU nrDNA and 12S SSU mtDNA sequences (Fig. 1).

The two morphotypes observed in the type locality and described above seem to differ only in the development level of the erect secondary branchlets. So, bushy, more or less Cladonia-like thallus with abundant erect secondary branchlets, which are common in the open areas has both types of thalline lobes, much thicker, mainly horizontally orientated main lobes and erect secondary branchlets. However, the first (main lobes) are usually not seen through the dense cover of the erect secondary branchlets or owing to the dust particles covering this portion of the thallus. The second morphotype, i.e. mainly "horizontal crusts" of densely compressed main lobes, which are more common under the crown layer 
of the endemic shrub species Thymus calcareus, differs in having only scarce erect portions and the "horizontal crust" of this lichen is better observable. However, it should be mentioned that the "horizontal crust" is well developed in both cases, but it is poorly observable, especially in the first case.

Specimens of Agrestia zerovii were sterile (no apothecia were observed), similarly to all Eurasian specimens of $A$. hispida s. str. (cf. SoH RABI et al. 2013a).

Unfortunately, SoHrabi et al. (2013a) did not mention the length of the main lobes and secondary branchlets of Agrestia hispida, probably they did not think that these characters are important for taxonomy of this species group. However, differences between $A$. zerovii and $A$. hispida s. str. prove that details on lobe morphology are important. In our opinion the descriptions of $A$. hispida s. str., and of the crustose $A$. hispida s. 1 . should be completed with data on the length of main lobes and secondary branchlets.

Agrestia hispida was illustrated in the Red data book of Ukraine (DIDUKH 2009) by photos of North American material, because it was fertile. It is necessary to emphasise based on the morphological differences between $A$. zerovii and $A$. hispida, that the Ukrainian material is quite different from the North American one. Differences of $A$. zerovii and $A$. hispida are also observable by comparison of the illustrations of $A$. hispida published in the Red data book of Ukraine (DIDUKH 2009) and illustrations of $A$. zerovii provided here. To our opinion Agrestia zerovii should be included in the next edition of the Red data book of Ukraine.

Colour photos of the Eurasian and American representatives of Agrestia hispida based on SoHrabi et al. (2011b) presented on the Myco-Lich website (www. myco-lich.com) and edited by SoHrABI et al. (2010) were also consulted within this revision, too.

Other specimens examined: Ukraine: Kharkiv oblast, Dvorichansky district, in the vicinity of Dvorichana settlement, Korobchyno zakaznik, 49 $50^{\prime}$ $00.5^{\prime \prime} \mathrm{N}, 37^{\circ} 40^{\prime} 27.7^{\prime \prime} \mathrm{E}$, the upper part of the slope, below the plantation, $2 \mathrm{~m}$ W of the road, leg. M. Kryvokhyzhaya, 19.06.2013 (paratype: KW-L 70658); the same locality, (paratype: KW-L 70659); the same locality, S exposure of the slope, in the middle part of the slope, W of the road, leg. M. Kryvokhyzhaya, 19.06.2013 (paratype: KW-L 70660); the same locality, S exposure of the slope, in the middle part of the slope, to $\mathrm{W}$ of the road, near the Thymus calcareus shrub, leg. M. Kryvokhyzhaya, 19.06.2013 (paratype: KW-L 70661); the same locality, S exposure of the slope, in the middle part of the slope, to $\mathrm{W}$ of the road, just close to the Thymus calcareus shrub, leg. M. Kryvokhyzhaya, 19.06.2013 (paratype: KW-L 70662). 

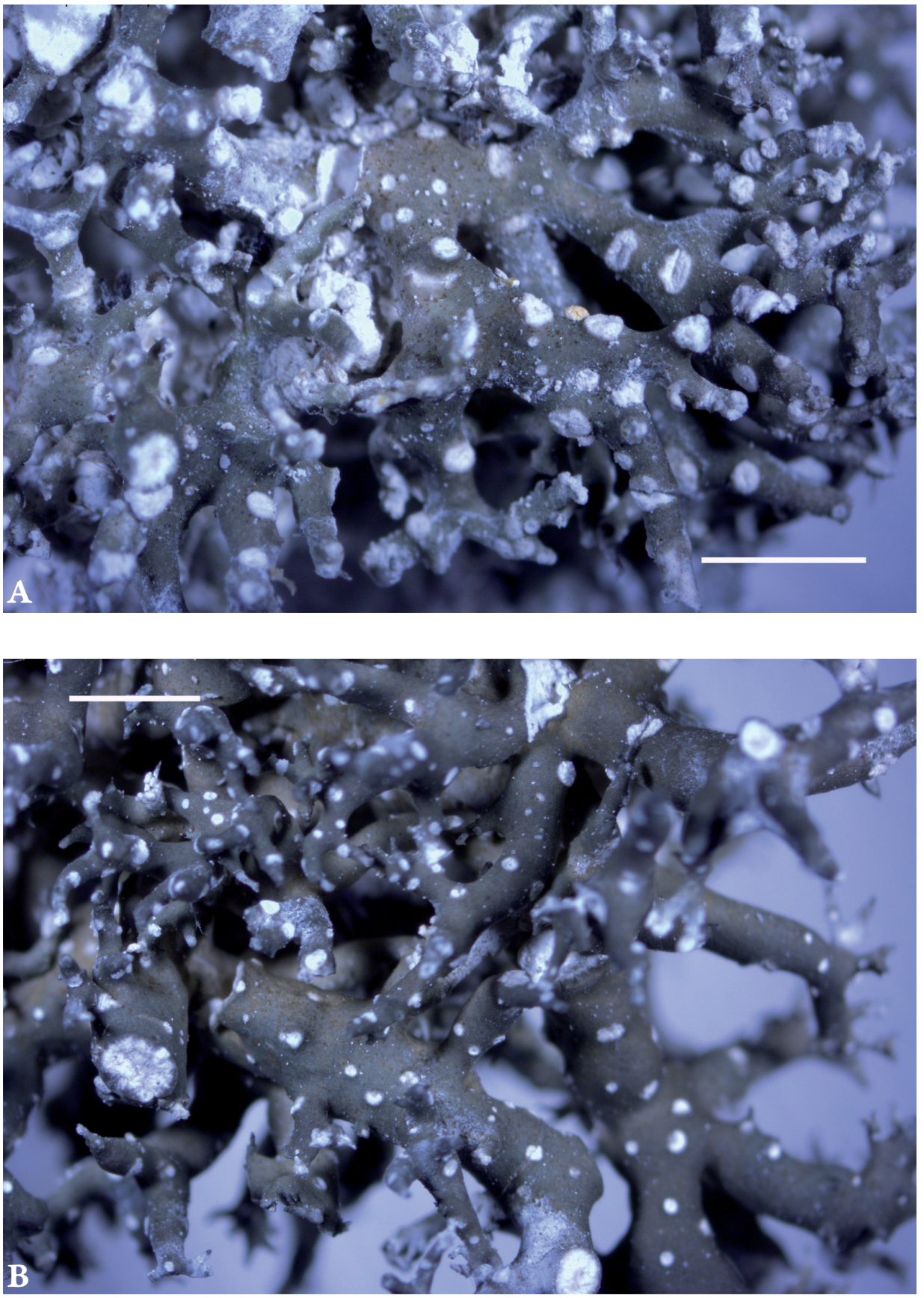

Fig. 4. Agrestia zerovii (holotype), enlarged main thalline lobes. Scale: A and B $=2 \mathrm{~mm}$. 

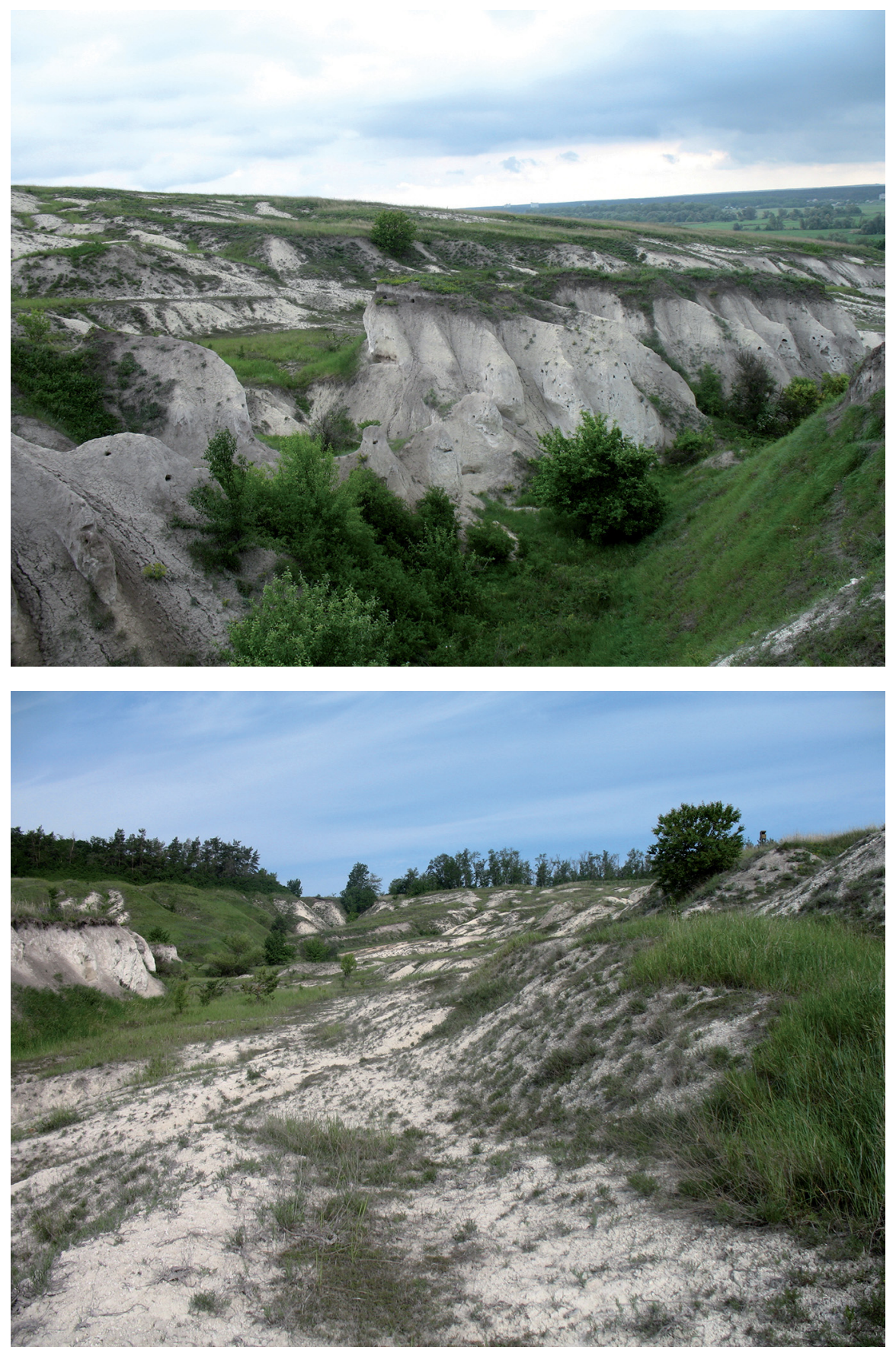

Fig. 5. General view of the type locality of Agrestia zerovii. 


\section{New combinations}

Chlorangium alpicola (Elenkin) S. Y. Kondr., A. B. Gromakova et Khodos., comb. nova [MycoBank no.: MB 813879]. - Basionym: Aspicilia alpicola Elenkin, Fl. Lishaynikov Sredney Rossii [Lichenes Florae Rossiae Mediae] 2: 222 (1907). E Circinaria alpicola (Elenkin) Sohrabi in Sohrabi et al., Mycol Progr. 12: 244 (2013). - Type: Kyrgyzstan. "Ad terram argillosam in regione alpina montium Tian-Shan (Kaschgariae: Werchnij Syrt 12,000 ft. ped)", 1889, Roborowsky in Elenkin, Lich. Fl. Ross. No. 24d (lectotype: H; isolectotype: LE (L2008), designated by SoHRABi and Aнti (2010)). = Aspicilia alpinodesertorum f. esculenta-alpina Elenkin in Izv. Imp. S.-Peterburgsk. Bot. Sada 1: 36 (1901) (16 July), as "esculenta alpine" or "esculenta (alpina)". = Aspicilia alpinodesertorum f. fruticulosofoliacea Elenkin in Izv. Imp. S.-Peterburgsk. Bot. Sada 1: 27, 36, 39, tab. 2, rows IX-X, figs 1-7 (1901), as "fruticuloso-foliacea". = Aspicilia fruticulosofoliacea (Elenkin) Sohrabi in Taxon 59: 627 (2010).

Chlorangium aschabadense (J. Steiner) S. Y. Kondr., A. B. Gromakova et Khodos., comb. nova [MycoBank no.: MB 813881]. - Basionym: Lecanora esculenta subsp. aschabadensis J. Steiner in Ann. Mycol. 8: 227 (1910). EAspicilia aschabadensis (J. Steiner) Mereschk., Trudi naturh. Ver. ksl. Univ. Kasan 43: 34 (1911). 三 Circinaria aschabadensis (J. Steiner) Sohrabi in Sohrabi et al., Mycol Progress 12: 249 (2013). - Type: Turkmenistan. "Regio trans-caspica: Aschabad [Ashgabat] ad fines Persiae”, sine dato, Sintenisin Zahlbruckner, Lich. Rarior. Exs. No. 32 (error “39”) (lectotype: W; isolectotypes: LE, PC, designated by SoнRABI and Aнті (2010)).

Chlorangium asperum (Mereschk.) S. Y. Kondr., A. B. Gromakova et Khodos., comb. nova [MycoBank no.: MB 813882]. - Basionym: Aspicilia desertorum var. aspera Mereschk. in Trudy Obshch. Estestvoisp. Imp. Kazansk. Univ. 43(5): 13 (1911). ELecanora aspera (Mereschk.) Tomin, Prir. Sel'sk. Khoz. Zasushl.-Pustyn. Obl. SSSR. 1/2: 4 (1927), nom. illeg., non. L. aspera Stizenb. (1890). 三 Aspicilia aspera (Mereschk.) Tomin, in Kopaczevskaja et al., Handbook of the lichens of the USSR 1: 198 (1971). E Circinaria aspera (Mereschk.) Sohrabi et Şenkard, in Sohrabi et al., Mycol Progr. 12: 265 (2013). - Type: Azerbaijan. "In rupibus calcareis e gub. Baku in Caucaso", 1893, Lipsky in Elenkin: Lich. Fl. Ross. No. $24 b$ (lectotype: LE (L 2017); isolectotypes: H (L 2016, L 2018), designated by SoHRABI et al. 2013a).

Chlorangium gyrosum (Sohrabi, Sipman, V. John et V. J. Rico) S. Y. Kondr., A. B. Gromakova et Khodos., comb. nova [MycoBank no.: MB 813885]. - Basionym: Circinaria gyrosa Sohrabi, Sipman, V. John et V. J. Rico, in Sohrabi et al., Mycol Progr. 12: 255 (2013). - Type: Iran, East Azerbaijan, Marand district, $32 \mathrm{~km} \mathrm{~N}$ of

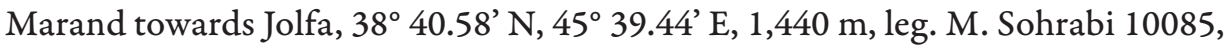
H. Sipman, U. Søchting, M. R. Asef, 2 Nov. 2007 (holotype: IRAN 14444; isotypes: $\mathrm{B}, \mathrm{H})$. 
Chlorangium sphaerothallinum (J. Steiner) S. Y. Kondr., A. B. Gromakova et Khodos., comb. nova [MycoBank no.: MB 813887]. - Basionym: Aspicilia calcarea var. sphaerothallina J. Steiner, Ann. Naturhist. Hofmus. 20: 379 (1907). EAspicilia sphaerothallina (J. Steiner) Szatala, Annln K. K. naturh. Hofmus. Wien 50: 527 (1940) [1939]. E Circinaria sphaerothallina (J. Steiner) Sohrabi, in Sohrabi et al., Mycol Progr. 12: 266 (2013). - As mentioned by So RA BI et al. (2013a) additional study is required before a lectotype specimen can be designated for this species.

\section{CONCLUSIONS}

Ukrainian as well as the whole Eurasian material of Agrestia hispida is in urgent need of revision to clarify the distribution of both $A$. zerovii and $A$. hispida. The inclusion of the type specimen of the genus Agrestia (i.e. A. cyphellata) and of further specimens of $A$. zerovii and $A$. hispida in the phylogenetic analysis is also very desirable.

The revision of the small species groups discussed above (i.e. Aspicilia epiglypta, Chlorangium sphaerothallinum, "Circinaria" fruticulosa, etc.) will clarify their relation to the genera Agrestia, Chlorangium, Sphaerothallina within the family Megasporaceae.

Acknowledgements - We are thankful to Maryna Kryvokhyzhaya (Kharkiv, Ukraine) for providing additional collection of $A$. zerovii, to Dr Anna Guttová (Bratislava, Slovakia) for the possibility to make illustrations of the new species, to Prof. Teuvo Ahti (Helsinki, Finland), Dr László Lőkös (Budapest, Hungary) and Dr Arne Thell (Lund, Sweden), as well as Natalie van de Wiele and Dr Shaun Pennycook (Auckland, New Zealand) for valuable comments to this manuscript.

Összefoglaló: Az Agrestia zerovii S. Y. Kondr., A. B. Gromakova et Khodos. új zuzmófaj az ukrán sztyeppzóna meszes talajain elterjedt, vándorló életmódot folytató Agrestia hispida fajkomplexből került leírásra. Az A. hispida-tól abban különbözik, hogy jóval vastagabb elsődleges telepi karéjokkal rendelkezik, melyek egy vastag vízszintes kérget alkotnak, továbbá a másodlagos ágacskák csúcsa nem fekete. A kombinált filogenetikai analízis (riboszomális DNS ITS, LSU, mitokondriális DNS SSU) a Megasporaceae család azon fajainak bevonásával történt, amelyekhez megbízható szekvenciaadatok álltak rendelkezésre. A kladogramon a Circinaria s. str. 5 klasszikus nemzetséget (Aspicilia, Circinaria, Lobothallia, Megaspora és Sagedia) tömörítő kládtól elkülönülten négy új, markáns klád vált el, az Agrestia, a Chlorangium, a Sphaerothallia s. str. és a "Circinaria" lacunosa komplex (a gyengén támogatott Sphaerothallia s. l. fajcsoport). Taxonómiai diverzitásuk részletes tárgyalása mellett az Agrestia J. W. Thomson, a Chlorangium Link és a Sphaerothallia Nees ex Eversm. nemzetségek újraértelmezése, visszaállítása, valamint több más aspicilioid zuzmófaj taxonómiai státusának rendezése javasolt további revíziós kutatásokat követően. Az analízis eredményeként 5 új kombinációt hajtottunk végre a Chlorangium Link nemzetségben ( $C$. alpicola, $C$. aschabadense, C. asperum, C. gyrosum, C. sphaerothallinum). 


\section{REFERENCES}

ANDREeVA, E. I. (1987): Flora sporovykh rasteniy Kazakhstana. Vol. 11, Lichenes, 3, Lecanorales, Physciales. - Nauka, Nauka Kazakhskoy SSR, Alma Ata (Almaty), 296 pp. (in Russian).

Arup, U., Søchting, U. and FrödÉn, P. (2013): A new taxonomy of the family Teloschistaceae. Nordic J. Bot. 31: 16-83. http://dx.doi.org/10.1111/j.1756-1051.2013.00062.x

Brodo, I. M. (1976): Lichenes canadenses exsiccati, Fasc. II. - Bryologist 79: 385-405. http://dx.doi.org/10.2307/3241935

Büdel, B. and Wessels, D. C. J. (1986): Parmelia hueana Gyeln., a vagrant lichen from the Namib Desert, SWA Namibia. I. Anatomical and reproductive adaptations. - Dinteria 18: 3-15.

Didukh, Ya. P. (ed.) (2009): Red data book of Ukraine. Vegetable kingdom. - Globalconsalting Press, Kiev, 912 pp.

Donkin, R. A. (1980): Manna: an historical geography. - Biogeographica 17: 1-161. http://dx.doi.org/10.1007/978-94-017-6117-8

Donkin, R. A. (1981): The “manna lichen" Lecanora esculenta. - Anthropos 76: 562-576.

Fedorenko, N. M., Stenroos, S., Thell, A., Kärnefelt, I. and Kondratyuk, S. Y. (2009): A phylogenetic analysis of xanthorioid lichens (Teloschistaceae, Ascomycota) based on ITS and mtSSU sequences. - Bibl. Lichenol. 100: 49-84.

Gromakova, A. B. (2013): New and rare species of lichens for the Left Bank part of Ukraine from cretaceous outcrops. - Ukr. Bot. J. 70(5): 664-668. (in Ukrainian).

Hafellner, J., Nimis, P. L. and Tretiach, M. (2004): New records of Aspicilia hispida from Italy and Greece. - Herzogia 17: 95-102.

IVAnova, N. V. and HAFEllneR, J. (2002): Searching for the correct placement of Megaspora by use of ITS1, 5.8S and ITS2 rDNA sequence data. - Bibl. Lichenol. 82: 123-140.

Kondratyuk, S., Jeong, M.-H., Yu, N.-H., Kärnefelt, I., Thell, A., Elix, J. A., Kim, J., Kondratyuk, A. S. and Hur, J.-S. (2013): Four new genera of teloschistoid lichens (Teloschistaceae, Ascomycota) based on molecular phylogeny. - Acta Bot. Hung. 55(3-4): 251-274. http://dx.doi.org/10.1556/ABot.55.2013.3-4.8

Kondratyuk, S. Y., Jeong, M.-H., Yu, N.-N., Kärnefelt, I., Thell, A., Elix, J. A., Kim, J., Kondratiuk, A. S. and Hur, J.-S. (2014a): A revised taxonomy for the subfamily Caloplacoideae (Teloschistaceae, Ascomycota) based on molecular phylogeny. - Acta Bot. Hung. 56(1-2): 93-123. http://dx.doi.org/10.1556/ABot.56.2014.1-2.10

Kondratyuk, S. Y., Kärnefelt, I., Thell, A., Elix, J. A., Kim, J., Jeong, M.-H., Yu, N.-H., Kondratiuk, A. S. and Hur, J.-S. (2014b): A revised taxonomy of the subfamily Xanthorioideae (Teloschistaceae, Ascomycota) based on molecular phylogeny. - Acta Bot. Hung. 56(1-2): 141-178. http://dx.doi.org/10.1556/ABot.56.2014.1-2.12

Kondratyuk, S. Y., Jeong, M.-H., Galanina, I. A., Yakovchenko, L. S., Yatsyna, A. P. and HuR, J.-S. (2014c): Molecular phylogeny of placodioid lichen-forming fungi reveal a new genus, Sedelnikovaea. - Mycotaxon 129(2): 269-282. http://dx.doi.org/10.5248/129.269

Kondratyuk, S. Y., Kärnefelt, I., Thell, A., Elix, J. A., Kim, J., Kondratiuk, A. S. and Hur, J.-S. (2015): Tassiloa, a new genus in the Teloschistaceae (lichenized ascomycetes). Graphis Scripta 27(1-2): 22-26.

Kou, X.-R., LI, S.-X., Ren, Q. (2013): Three new species and one new record of Lobothallia from China. - Mycotaxon 123: 241-249. http://dx.doi.org/10.5248/123.241

Kulakov, V. G. (2002): Foliose and fruticulose lichens of the Lower Volga Region. - Regional'nyy centr o izucheniyu i sokhraneniyu bioraznoobraziya, Volgograd, $125 \mathrm{pp}$. (in Russian)

Kula kov, V. G. (2003): Foliose and fruticulose lichens of Baskunchak Lake vicinity. - Bot. Zhurn. 88: 96-104. (in Russian) 
MeresCh Kows KY, C. (1911): Excursion liche'nologique dans les steppes Kirghises (Mont Bogdo). - Trudy Obsc. Estestvoisp. Imp. Kazansk. Univ. 43: 1-42.

Miadeikowska, J., Kauff, F., Hofstetter, V., Fraker, E., Grube, M., Hafellner, J., Reeb, V., Hodkinson, B. P., Kukwa, M., LÜCking, R., Hestmark, G., Otalora, M. G., Rauhut, A., Büdel, B., Scheidegger, C., Timdal, E., Stenroos, S., Brodo, I., Perlmutter, G. B., Ertz, D., Diederich, P., Lendemer, J. C., May, P., Schoch, C. L., ArNold, A. E., Gueidan, C., Tripp, E., Yahr, R., Robertson, C. and Lutzoni, F. (2006): New insights into classification and evolution of the Lecanoromycetes (Pezizomycotina, Ascomycota) from phylogenetic analyses of three ribosomal RNA- and two protein-coding genes. - Mycologia 98(6): 1088-1103. http://dx.doi.org/10.3852/mycologia.98.6.1088

Nordin, A., Owe-Larsson, B. and Tibell, L. (2011): Two new Aspicilia species from Fennoscandia and Russia. - Lichenologist 43(1):27-37.http://dx.doi.org/10.1017/S0024282910000629

Nordin, A., SAVIČ, S. and TiBeLL, L. (2010): Phylogeny and taxonomy of Aspicilia and Megasporaceae. - Mycologia 102: 1339-1349. http://dx.doi.org/10.3852/09-266

Nordin, A., Tibell, L. and Owe-Larsson, B. (2007): A preliminary phylogeny of Aspicilia in relation to morphological and secondary product variation. - Bibl. Lichenol. 96: 247-266.

Owe-Larsson, B., Nordin, A. and Tibell, L. (2007): Aspicilia. - In: Nash, T. H., Gries, C. and Bungartz, F. (eds): Lichen flora of the Greater Sonoran Desert Region. 3. Lichens Unlimited, Arizona State University, Tempe, Arizona, pp. 61-108.

Owe-Larsson, B., Nordin, A., Tibell, L. and Sohrabi, M. (2011): Circinaria arida spec. nova and the Aspicilia desertorum complex. - Bibl. Lichenol. 106: 235-246.

Oxner, A. N. (1971): Aspicilia Massal. - In: Kopaczevskaja, E. F., Makarevicz, M. F., Oxner, A. N. and Rassadina, K. A. (eds): Handbook of the lichens of the USSR. Vol. 1. Nauka, Leningrad, pp. 146-217. (in Russian)

OXNer, A. M. (2010): Flora of the Lichens of Ukraine, in two volumes. Vol. 2(3). - Nauk. dumka, Kyiv, 663 pp.

Poelt, J. (1969): Bestimmungsschlüssel europäischer Flechten. - J. Cramer, Lehre, 757 pp.

Roux, C., Nordin, A., Tibell, L. and Sohrabi, M. (2011): Some poorly known or new Aspicilia species from Pyrenees-Orientales (France). - Bull. Soc. Linn. Provence 14: 177-227.

Schmitt, I., Yamamoto, Y. and Lumbsch, T. (2006): Phylogeny of Pertusariales (Ascomycotina): Resurrection of Ochrolechiaceae and new circumscription of Megasporaceae. - J. Hattori Bot. Lab. 100: 753-764.

Schmull, M., Miadeikowska, J., Pelzer, M., Stocker-Wörgötter, E., Hofstetter, V., Fraker, E., Hodkinson, B. P., Reeb, V., Kukwa, M., Lumbsch, H. T., Kauff, F. and LutZONI, F. (2011): Phylogenetic affiliations of members of the heterogeneous lichen-forming fungi of the genus Lecidea sensu Zahlbruckner (Lecanoromycetes, Ascomycota). - Mycologia 103(5): 983-1003. http://dx.doi.org/10.3852/10-234

Seaward, M. R. D., Sipman, H. J. M. and Sohrabi, M. (2008): A revised checklist of lichenized, lichenicolous and allied fungi for Iran. - Sauteria 15: 459-520.

Sohrabi, M. and Aнti, T. (2010): Nomenclatural synopsis of the Old World's 'manna' lichens of the genus Aspicilia (Megasporaceae). - Taxon 59: 628-636.

http://dx.doi.org/10.2307/25677623

Sohrabi, M., Ahti, T. and Litterski, B. (2011a): Aspicilia digitata sp. nov., a new vagrant lichen from Kyrgyzstan. - Lichenologist 43: 39-46. http://dx.doi.org/10.1017/S0024282910000538

Sohrabi, M., Myllys, M. and Stenroos, S. (2010): Successful DNA sequencing of a 75 yearold herbarium specimen Aspicilia aschabadensis (J. Steiner) Mereschk. - Lichenologist 42: 626-628. http://dx.doi.org/10.1017/S0024282910000344 
Sohrabi, M., Stenroos, S., Högnabba, F., Nordin, A. and OWe-Larsson, B. (2011b): Aspicilia rogeri sp. nov., (Megasporaceae) and other allied vagrant species in North America. Bryologist 114: 178-189. http://dx.doi.org/10.1639/0007-2745-114.1.178

Sohrabi, M., Leavitt, S. D., Rico, V. J., Halici, M. G., Shrestha, G. and Stenroos, S. (2013b): Teuvoa, a new lichen-forming fungal genus in Megasporaceae (Ascomycota: Pertusariales), including Teuvoa junipericola sp. nov. - Lichenologist 45: 347-360.

http://dx.doi.org/10.1017/S0024282913000108

Sohrabi, M., Stenroos, S., Myllys, L., Søchting, U., Ahti, T. and Hyvönen, J. (2013a): Phylogeny and taxonomy of the 'manna lichens'. - Mycol. Progr. 12: 231-269. http://dx.doi.org/10.1007/s11557-012-0830-1

Szatala, Ö. (1957): Prodromus einer Flechtenflora des Irans. - Annls hist.-nat. Mus. natn. Hung., ser. nov. 8: 101-154.

Thomson, J. W. (1961): Agrestia cyphellata, a new genus and species of lichen in the Usneaceae. - Bryologist 63(4): 246-250.

Valadbeigi, T., Nordin, A. and Tibell, L. (2011): Megaspora rimisorediata (Pertusariales, Megasporaceae), a new sorediate species from Iran and its affinities with Aspicilia sensu lato. Lichenologist 43(4): 285-291. http://dx.doi.org/10.1017/S0024282911000211

Wedin, M., Wiklund, E., Crewe, A., Doring, H., Ekman, S., Nyberg, A., Schmitt, I. and LumbSCH, H. T. (2005): Phylogenetic relationships of Lecanoromycetes (Ascomycota) as revealed by analyses of mtSSU and nLSU rDNA sequence data. - Mycol. Res. 109 (2): 159-172. http://dx.doi.org/10.1017/S0953756204002102

(submitted: 04.06.2015, accepted 04.11.2015) 